\title{
The Effect of Dehulling Lupine Seeds (Lupinus albus L.) from Low-Alkaloid Varieties on the Chemical Composition and Fatty Acids Content
}

\author{
DANUT IOAN STRUTI ${ }^{1}$, DANIEL MIERLITA ${ }^{2 *}$, DANIEL SIMEANU ${ }^{3 *}$, \\ IOAN MIRCEA POP ${ }^{3 *}$, CLAUDIA TEREZIA SOCOL ${ }^{2}$, TUDOR PAPUC ${ }^{1}$, \\ ADRIAN MAXIMILIAN MACRI ${ }^{1}$ \\ ${ }^{1}$ University of Agricultural Sciences and Veterinary Medicine Cluj-Napoca, 3-5 Calea Manastur Str., 400372, Cluj-Napoca, \\ Romania \\ ${ }^{2}$ University of Oradea, Department of Animal Science, 1 University Str., 410087, Oradea, Romania \\ ${ }^{3}$ University of Agricultural Sciences and Veterinary Medicine of Iasi, 3 Mihail Sadoveanu Alley, 700490, Iasi, Romania
}

\begin{abstract}
The aim of this study was to analyze the effect of dehulling white lupine seeds (Lupinus albus, cultivar Amiga) on the raw chemical composition and nutritional profile of lipids. There was no significant differences $(p>0.05)$ between whole and dehulled lupine seeds in respect of their content in dry matter, ether extract, crude ash and nitrogen-free extract. However, the dehulled lupine seeds had a higher $(p<0.05)$ crude protein level $(51.69 \%$ of DM) than whole seeds $(43.16 \%$ of DM), and a lower $(p<0.05)$ crude fiber content $(4.35 \%$ of DM) compared to that of whole seeds $(14.15 \%$ of DM). The fatty acids profile is not affected $(p>0.05)$ by the dehulling process. Oleic acid (C18:1 cis-9) is the main fatty acid in lupine seeds, and the level of monounsaturated fatty acids (MUFA) is slightly higher in whole seeds. The n-3/n-6 report is adequate in both whole (0.88) and dehulled (0.94) seeds, and the favorable polyunsaturated index (PI) indicates the high content of polyunsaturated fatty acids (PUFA), which indicates that lupine seeds are a valuable source of essential fatty acids. Also, lupine seeds are characterized by favorable values of the thrombogenic (0.18) and atherogenic (0.14) indexes, and an appropriate hypocholesterolemic/hypercholesterolemic index value, features considered important for human health and animal nutrition.
\end{abstract}

Keywords: dehulling, chemical composition, fatty acids profile, white lupine seeds

\section{Introduction}

In the Central and Eastern Europe, lupine species (Lupinus spp.) from low-alkaloid varieties are widely cultivated and are considered an optimum alternative to reduce the dependence on soybeen imports [1]. This is due to the suitability for sustainable production, nutritional qualities of seeds, potential health benefits and well acceptability to the consumers [2].

The lupine plant is considered adequate for sustainable agriculture due to its capacity to fix atmospheric nitrogen in the soil [3] and its suitability for crop rotation, being a good precursory for other plant cultures [4]. However, the nutrient content of lupine seeds and their quality are influenced by the species, cultivars, selected agrotechniques and pedoclimatic factors for plant growth [5]. New sweet lupine cultivars from low-alkaloid varieties (less $0.02 \%$ ) do not require heat treatment of the seeds in order to eliminate thermolabile compounds, like in the case of soybeans, because of their low content of protease inhibitors, tannins, saponins, lectins. In addition, it does not raise ethical issues, as they do not originate from genetically modified organisms [6, 7]. However, the high content of cellulose and non-starch polysaccharides represent antinutritional factors for monogastric animals [8].

In recent years there is an increasing tendency to include lupine seeds in human nutrition. Thereby, lupine flour can be used as a food ingredient in bakery and pasta products, being considered a glutenfree functional food [9-11]. In addition, lupine seeds are a good source of bioactive compounds, which creates new opportunities for the food industry $[12,13]$. Lupine seeds are suitable for current trends

*email:dadimierlita@yahoo.com;dsimeanu@uaiasi.ro;popmirceais@yahoo.com 
that promote the consumption of products with high amounts of polyunsaturated fatty acids from the Omega 3 and Omega 6 categories, with an hypocholesterolemic effect [14-17].

Due to the fact that lupine seeds are a promising resource for solving the challenges of high food demand for human consumption and farm animal feeds, numerous researches are focused on understanding the nutritional properties and qualities of lupine seeds [18-20]. From the lupine species commonly cultivated, $L$. albus seeds have a high content of crude protein (35-43\%) [21] and fat (8$12 \%$ ) [22]. From a nutritional point of view, white lupine seeds are characterized by a high biological value of protein and a good quality of lipids. The fatty acids profile reveals a high proportion of unsaturated fatty acids, as well as a favorable report of omega-3 / omega- 6 fatty acids [23]. Lipids from L. albus (cv. Amiga) seeds represent a valuable source of essential fatty acids, with an n-3/n-6 fatty acids report, appropriate for the nutrition of humans and farm animals [24].

Some researches highlight the possibility to improve the nutritional value of lupine seeds by applying methods such as dehulling, germination [18], roasting [25], autoclaving, or fermentation [26]. Some of the studies show that the dehulling process can have a positive effect on the content of certain nutrients. Dehulling is a physical method of removing the hulls for a better use of the kernel [27]. A relatively limited number of researches report the effect of dehulling L. albus seeds on the chemical composition and nutritional quality of the seeds [28, 29]. Barneveld et al. [30] presented lupine seeds as having a protein level comparable to that of soybean meal if they are dehulled. In human foodstuff, lupine seeds are generally used as kernel [31].

In the view of these aspects, as well as the nutritional characteristics of lupine seeds, the purpose of this research is to analyze the effect of dehulling L. albus (cv. Amiga) seeds on the raw chemical composition and nutritional quality of lipids.

\section{Materials and methods}

\subsection{Raw material}

The Lupinus albus seeds used in this research belong to the Amiga cultivar and are from lowalkaloid varieties (under $0.025 \%$ alkaloids). The white lupine was cultivated in Romania in 2018, in north-eastern region of Transylvania $\left(47^{\circ} 17^{\prime} 03^{\prime} \mathrm{N}, 23^{\circ} 40^{\prime} 34^{\prime \prime} \mathrm{E}\right)$. The pedoclimatic conditions of plant growth are represented by a brown podzolic soil with a clay texture. The average temperature of the vegetation period (season April - August) was about $18^{\circ} \mathrm{C}$ and the average rainfall was $455 \mathrm{~mm}$.

The dehulling of white lupine seeds utilized for the chemical analysis was realized manually. The proportions of hulls and kernel were also recorded. Both categories of seeds (whole and dehulled) were finely ground with a laboratory mill and pass through a $300 \mu \mathrm{m}$ sieve [29]. The samples was marked distinctly in Lupine Whole Seeds (LWS) and Lupin Dehulled Seeds (LDS).

\subsection{Laboratory analysis}

The chemical composition of whole and dehulled white lupine seeds was performed according to the standard procedures established by AOAC International [32] for the determination of the dry matter (934.01), crude protein (954.01), crude fat (920.39), crude fiber (978.10) and crude ash (942.05). The results obtained are reported at a dry matter basis. Dry matter (DM) of seeds was determined by drying at $105^{\circ} \mathrm{C}$ for 5 hours, until constant mass was reached. Crude protein (CP) was determined by the Kjeldahl method ( $\mathrm{N}$ x 6.25) and crude fat was determined as ether extract (EE) by the Soxhlet extraction method. The crude fiber $(\mathrm{CF})$ was determined by acid hydrolysis (with $\mathrm{HCl}$ ), followed by basic hydrolysis (with $\mathrm{KOH}$ ), and the crude ash (CA) content was determined by calcination (the process was carried out in porcelain crucibles, at $580^{\circ} \mathrm{C}$ for 5 hours). The nitrogen-free extract (N-FE) was calculated by difference, as follows:

$$
\mathrm{N}-\mathrm{FE}=100 \%-\mathrm{CP} \%-\mathrm{EE} \%-\mathrm{CA} \%-\mathrm{CF} \% \text {. }
$$

The organic matter $(\mathrm{OM})$ was also calculated by difference, as follows:

$$
\mathrm{OM}=100 \%-\mathrm{CA} \% \text {. }
$$


The metabolizable energy of lupine seeds (whole and dehulled) was calculated considering the correction related to the nitrogen balance (EMAn). For this calculation, the equation proposed by Sibbald [33] was used:

$$
\text { EMAn }=3951+54,4 \mathrm{MG}-88,7 \mathrm{CB}-40,8 \mathrm{Ce},
$$

where: $\mathrm{MG}=$ ether extract; $\mathrm{CB}=$ crude fiber; $\mathrm{Ce}=$ ash.

Extraction and identification of fatty acid methyl esters (FAME) from white LWS and LDS was performed by the gas chromatography technique with mass spectrometry detection. The equipment used for the analysis is a Perkin Elmer Chromatographic system with mass spectrometer detector (GCMS), composed of Clarus 680 gas-chromatograph (with programmable injector and thermostat oven) and Clarus SQ8T quadrupole mass spectrometer. The chromatographic column used is Elite-Wax with stationary polar phase Polyethylene glycol (PEG), length $30 \mathrm{~m}$, internal diameter $0.25 \mathrm{~mm}$ and $1.0 \mu \mathrm{m}$ film thickness. Injection port temperature was $220^{\circ} \mathrm{C}$, the sample volume injected was $1.0 \mu \mathrm{l}$, helium carrier gas at flow rate of $1.5 \mathrm{ml} / \mathrm{min}$ and splitting ratio $40: 1$. The temperature gradient was $100^{\circ} \mathrm{C}$ during 2 min standstill and $1 \mathrm{~min}$ stationary at $250^{\circ} \mathrm{C}$. MS operating parameters were: transfer line temperature $150^{\circ} \mathrm{C}$; source temperature $150^{\circ} \mathrm{C}$; multiplier 1500 ; solvent delay $0-1.5 \mathrm{~min}$.

The principle of the method consists in the chromatographic separation of the fatty acid mixture from lupine oil extract, initially subjected to esterification with sodium metanoate, on a capillary column with a weak polar stationary phase, followed by the fragmentation of their molecules by electronic impact in the ionization source. The identification and quantification of the FAME are performed on the basis of the target and qualifying ions. The fatty acid methyl esters from LWS and LDS were prepared after a lipid saponification phase, followed by esterification under a boron trifluoride (15\% vol.) catalyst. Fatty acids resulted from the analyzed samples were obtained by comparing the relative retention time of the FAME with that of the certified standard (Mix FAME Supelco 37). The individual fatty acid concentration is expressed in $\mathrm{g}$ FAME/100 $\mathrm{g}$ of total FAME identified.

\subsection{Evaluation of Lipids Nutritional Quality}

The quality of the lipid fraction from the lupine seeds was evaluated on the basis of the fatty acids profile and the relationships established among them. The identified fatty acids are presented as a mean for 8 determinations $(n=8)$, being grouped as follows: sum of saturated fatty acids $(\Sigma$ SFA= $\mathrm{C} 10: 0+\mathrm{C} 12: 0+\mathrm{C} 14: 0+\mathrm{C} 15: 0+\mathrm{C} 16: 0+\mathrm{C} 18: 0+\mathrm{C} 20: 0+\mathrm{C} 22: 0)$; sum of monounsaturated fatty acids $(\Sigma$ MUFA $=\mathrm{C} 16: 1+\mathrm{C} 18: 1$ cis $-9+\mathrm{C} 20: 1 \mathrm{n}-9+\mathrm{C} 22: 1 \mathrm{n}-9)$; sum of polyunsaturated fatty acids $(\Sigma$ PUFA $=$ C18:2 n-6 + C20:2 n-6 + C18:3 n-3 + C20:3 n-3 + C20:5 n-3 + C18:3 n-6) [22].

The n-3 / n- 6 report of fatty acids is expressed as the ratio of fatty acids from the Omega- 3 and Omega-6 series.

The polyunsaturated index (PI) of whole and dehulled white lupine seeds was calculated according equation proposed by Timmons [34]:

$$
\mathrm{PI}=\mathrm{C} 18: 2 \mathrm{n}-6+(\mathrm{C} 18: 3 \mathrm{n}-3 \times 2)
$$

In order to highlight the relevance for human health, based on the identified FAME, the atherogenic (AI) and thrombogenic (TI) indexes of lipids from whole and dehulled seeds were calculated, according to Ulbricht and Southgate [35]:

$$
\begin{gathered}
\mathrm{AI}=(\mathrm{C} 12: 0+\mathrm{C} 16: 0+4 \times \mathrm{C} 14: 0) /[\Sigma \mathrm{MUFA}+\Sigma(\mathrm{n}-6)+\Sigma(\mathrm{n}-3)] \\
\mathrm{TI}=(\mathrm{C} 14: 0+\mathrm{C} 16: 0+\mathrm{C} 18: 0) /[0.5 \times \Sigma \mathrm{MUFA}+0.5 \times \Sigma(\mathrm{n}-6)+ \\
+3 \times \Sigma(\mathrm{n}-3)+\Sigma(\mathrm{n}-3) / \Sigma(\mathrm{n}-6)] .
\end{gathered}
$$

The ratio between fatty acids with hypocholesterolemic $(\mathrm{h})$ and hypercholesterolemic $(\mathrm{H})$ effect was calculated using the equation proposed by Fernandez et al. [36]: 


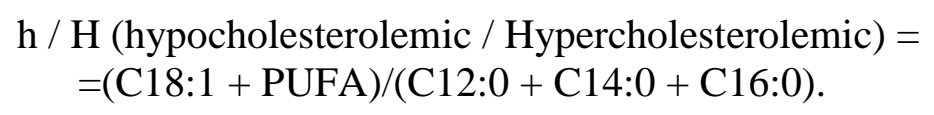

\subsection{Statistical analyzes}

The chemical analyzes results are expressed as an average of ten $(n=10)$ determinations for the raw chemical composition and as an average of eight $(\mathrm{n}=8)$ determinations for fatty acids analysis $(\mathrm{n}$ $=8$ ), for both LWS and LDS. The statistical software Graph Pad Prism version 8.3.0 (538) was used for the statistical interpretation of the data. The statistical test used to evaluate differences is the Tukey Test (Tukey Honest Significant difference). The significance level for detecting statistical differences was set at $\mathrm{p}<0,05$.

\section{Results and discussions}

\subsection{The Effect of Dehulling Lupine Seeds on the Raw Chemical Composition}

After dehulling, white lupine seeds (cv. Amiga) contain $17.72 \%$ hulls and $82.28 \%$ kernel. Večerek et al. [37] report a higher level of hulls $(22-24 \%)$ and, therefore, a lower level of kernel (76-78\%), for a several lupine varieties. We consider that these differences are due to the lupine genotype used, but also to the agroclimatic conditions, being known that on less valuable land and under a lower temperature conditions, the proportion of kernel and its content in nutrients decrease.

The raw chemical composition of whole and dehulled seeds of Lupinus albus (cv. Amiga) is presented in Table 1.

Table 1. The effect of dehulling L. albus cv. Amiga seeds on the raw chemical composition and energy value (\% of DM)

\begin{tabular}{ccccccccc}
\hline \multirow{2}{*}{ Specification } & \multicolumn{3}{c}{ Whole seeds } & \multicolumn{3}{c}{ Dehulled seeds } \\
\cline { 2 - 7 } & $\begin{array}{c}\text { Mean } \\
(\mathrm{n}=10)\end{array}$ & $($ min.-max. $)$ & $\mathrm{SD}^{1}$ & $\begin{array}{c}\text { Mean } \\
(\mathrm{n}=10)\end{array}$ & $($ min.-max. $)$ & $\mathrm{SD}^{1}$ \\
\hline Dry matter $(\mathrm{DM})$ & 92.40 & $92.26-92.51$ & 0.09 & 91.26 & $91.10-91.42$ & 0.12 & $\mathrm{~ns}$ \\
\hline Crude protein $(\mathrm{CP})$ & 43.16 & $42.28-43.98$ & 0.61 & 51.69 & $51.11-52.15$ & 0.31 & $*$ \\
\hline Ether extract $(\mathrm{EE})$ & 10.59 & $10.23-10.99$ & 0.27 & 11.67 & $10.75-12.86$ & 0.70 & $\mathrm{~ns}$ \\
\hline Crude fibre $(\mathrm{CF})$ & 14.15 & $12.79-15.01$ & 0.63 & 4.35 & $2.9-5.55$ & 0.66 & $*$ \\
\hline Crude ash $(\mathrm{CA})$ & 3.96 & $3.92-4.00$ & 0.03 & 3.89 & $3.75-3.97$ & 0.09 & $\mathrm{~ns}$ \\
\hline N-FE & 28.14 & $26.37-30.14$ & 1,03 & 28.41 & $27.51-30.29$ & 0.84 & $\mathrm{~ns}$ \\
\hline Organic matter $(\mathrm{OM})$ & 96.04 & $96.00-96.08$ & 0.09 & 96.11 & $96.03-96.25$ & 0.12 & $\mathrm{~ns}$ \\
\hline EMAn kcal/kg & 3110.30 & $3047.24-$ & 54.55 & 4041.39 & $3904.78-4147.27$ & 72.98 & $*$ \\
\hline
\end{tabular}

${ }^{1}$ SD-standard deviation; ${ }^{2} p: n s-p>0.05 ; *-p<0.05$;

N-FE:nitrogen-free extract (calculated values: $100 \%-C P \%-E E \%-C F \%-C A \%$ ); $O M=100-C A \%$;

EMAn - Metabolisable energy corrected to nitrogen balance, calculated according to Sibbald [33].

The results highlight that the dehulled lupine seeds contain a higher level of crude protein and a lower amount of crude fibre, compared to whole seeds.

Through dehulling lupine seeds, the CP content increased $(p<0.05)$ from $43.16 \%$ to $51.69 \%$ of DM. This difference represents an increase with $19.76 \%$ in the protein level. Similarly, Písarríková et al. [28] show for L. albus (cv. Butan) dehulled seeds a crude protein level (43.57\% of DM) higher than in the whole seeds (38.48\% of DM). Also for the white lupine seeds, but cv. Multitalia, Laudadio and Tufarelli [38] show the increase of the crude protein level from $35.50 \%$ of DM (in whole seeds) to $42.93 \%$ of DM (in dehulled seeds). The literature also reports a similar effect of dehulling on CP content for other lupine species. Thus, in L. angustifolius cv. Boregine, the protein level increases from $25.01 \%$ to $31.10 \%$ of DM in the dehulled seeds [39]. For L. luteus cv. Amulet, the data highlight that the level of crude protein in whole seeds is $42.80 \%$ of DM and in the dehulled seeds the level is 
$54.40 \%$ of DM [40]. A high protein level in the kernel (55.3\% of DM) is reported by Bähr et al. [31] for L. luteus cv. Bornal.

The content in ether extract (EE) does not change $(p>0.05)$ as a result of dehulling. However, in relative values, the EE level is higher by $10.2 \%$ in LDS, compared LWS. Similar situations are highlighted by the scientific literature, which reveal a relatively similar effect of dehulling on the EE content, but with some specificities/particularities depending on the species. Thus, Písaríḱková et al. [28] present a higher increase in EE content, from by $7.91 \%$ of DM in whole seeds, to the $10.23 \%$ of DM in dehulled seeds for white lupine ( $c v$. Bhutan). Similarly, Laudadio and Tufarelli [38] report for cv. Multitalia an EE level in whole seeds by $8.81 \%$ of DM and in dehulled seeds by $9.30 \%$ of DM. For $c v$. Hamburg, Saez et al. [29] highlight a more pronounced difference between the EE level in whole seeds and dehulled seeds (4.00 vs. 10.30\% of DM). For other lupine species, the effect of dehulling on the EE level is also in accordance with the present research. Thus, for L. angustifolius the level of EE is lower in whole seeds (5.42\% of DM) than in dehulled seeds (6.47\% of DM) [39]. For several varieties of dehulled blue lupine seeds, Bähr et al. [31] report an EE content between $6.8-9.8 \%$ of $\mathrm{DM}$, and for L. luteus (cv. Bornal) a level of $8.2 \%$ of DM.

The level of crude fibre $(\mathrm{CF})$ decreased $(p<0.05)$ as a result of dehulling lupine seeds. This is because the highest quantity of cellulose is concentrated in the hull, and by removing the hulls, a $69.26 \%$ decrease in the initial CF content (from LWS) is achieved. The level of CF obtained by us in LWS (14.15\% of DM) is similar to that reported by Saez et al. [29] at cv. Hamburg (13.50\% of DM), and after dehulling it decreases comparably (4.35 vs. 5.70\%). Compared to our results, Laudadio and Tufarelli [38] obtained a lower CF content (11.97\% of DM) in white lupine whole seeds, but higher in dehulled seeds (8.01\% of DM). Písaříková et al. [28] report a higher CF content in the whole seeds of L. albus (15.26\% of DM) and lower in dehulled seeds (3.77\% of DM). Mieczkowska et al. [40] reports relatively similar results for L. luteus, where the high proportion of CF in whole seeds (16.9\% of DM) decreases considerably after dehulling (3.8\% of DM). The high fibre content of L. albus seeds represent an antinutritional factor for monogastric animals, because they cannot efficiently assimilate these structural compounds of the cell walls (represented by cellulose, hemicellulose and pectin) due to the lack of specific endogenous enzymes [6]. Therefore, the nutritional value of lupine seeds for monogastric animals is considerably improved by dehulling [6, 29].

The nitrogen-free extract $(\mathrm{N}-\mathrm{FE})$ content does not show changes $(\mathrm{p}>0.05)$ as a result of dehulling. There is only a slight increase of N-FE in LDS compared to LWS, by 0.27 percentage points. A more pronounced increase is highlighted in the study conducted by Písaríková et al. [28], where the N-FE level in dehulled seeds (L. albus, cv. Butan) is higher with 5.27 percentage points (34.24 vs. $39.51 \%$ of DM). However, a clear decrease of the N-FE level after dehulling of lupine seeds (cv. Hamburg) is reported by Saez et al. [29]. Thus, the N-FE was $47.8 \%$ of DM in whole seeds and $38.3 \%$ of DM in dehulled seeds.

The content of crude ash (CA) does not presents changes $(p>0.05)$ as a result of dehulling seeds. Some minerals, such as Phosphorus [41], are concentrated in the lupine hulls. Thereby, after removal, the level of CA decreased slightly. However, other studies highlight the increase in the ash level as a result of dehulling white lupine [28, 29, 38]. Volek et al. [42] report a crude ash level by $2.5 \%$ of DM for cv. Amiga lupine hulls. Mera-Zúñiga et al. [39] show for L. angustifolius (cv. Boregine) that the level in crude ash is slightly lower in the whole seeds (3.81\% of DM) than in dehulled seeds $(3.93 \%$ of DM). This is also reported by Mieczkowska et al. [40] for L. luteus, obtaining a level of 5.3\% crude ash in the whole seeds and by $6.4 \%$ of DM in dehulled seeds.

The dehulling process influences $(p<0.05)$ the level of metabolizable energy corrected on the basis of nitrogen balance (AMEn) of lupine seeds. This increase in the AMEn value from 3110.30 $\mathrm{kcal} / \mathrm{kg} \mathrm{DM}$ in LWS to $4041.39 \mathrm{kcal} / \mathrm{kg} \mathrm{DM}$ in LDS, highlights the potential of improving the AMEn value by dehulling. Other research present a higher EMAn value $(3326.9 \mathrm{kcal} / \mathrm{kg} \mathrm{DM})$ for whole $L$. albus seeds (cv. Energy), as well as a lower value (2697.09 $\mathrm{kcal} / \mathrm{kg} \mathrm{DM})$ in case of cv. Lublanc [43]. 


\subsection{The Effect of Dehulling Lupine Seeds on the Nutritional Quality of Lipids}

The nutritional value of fats is proven by the content and structure of the fatty acids, as well as by the ratio between them [41]. The content and profile of the fatty acids in lupine seeds is dependent on the species, variety and pedoclimatic conditions [23, 44].

In the present research, the fatty acid contents of whole and dehulled white lupine seeds are presented in Table 2. According to the data from Table 2, white lupine seed lipids are well represented in monounsaturated fatty acids (MUFA) and polyunsaturated fatty acids (PUFA), and oleic acid (C18:1 cis-9) and linoleic acid (C18:2 n-6) are found in the highest concentration, respectively. From the quantified saturated fatty acids (SFA), the palmitic acid (C16:0) is found in the highest proportion. Similarly, other studies highlight comparable values of fatty acids in white lupine whole seeds [23, 45, 46]. For example, Chiofalo et al. [22] report for two cultivars of $L$. albus a lower content in palmitic (7.76 - 7.87\% FAME) and stearic acid (1.70 - 1.87\% FAME), but a higher content of behenic acid (3.75 - 4.75\% of FAME) compared with what we obtained in LWS. For L. luteus varieties, the values reported by the authors for individual SFA are higher than those we obtained only in the case of behenic acid (5.74 - $6.56 \%$ of FAME).

Table 2. The effect of dehulling on the fatty acid profile of L. albus cv. Amiga seeds g / 100 g total FAME

Fatty acid methyl esters (FAME)

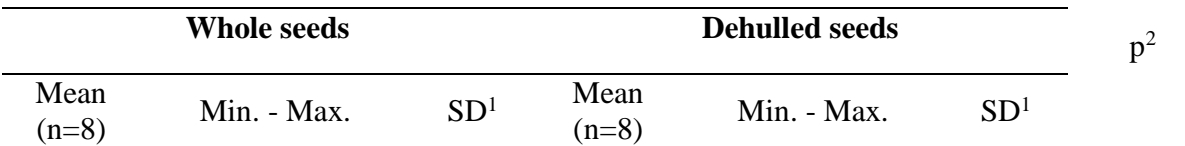

\begin{tabular}{|c|c|c|c|c|c|c|c|c|}
\hline \multicolumn{9}{|c|}{ Saturated Fatty Acids } \\
\hline Capric & C10:0 & 0.05 & $0.04-0.06$ & 0.01 & 0.04 & $0.04-0.05$ & 0.01 & ns \\
\hline Lauric & C12:0 & 0.09 & $0.07-0.10$ & 0.01 & 0.05 & $0.03-0.07$ & 0.01 & ns \\
\hline Myristic & C14:0 & 0.26 & $0.22-0.29$ & 0.02 & 0.22 & $0.21-0.24$ & 0.01 & ns \\
\hline Pentadecanoic & C15:0 & 0.12 & $0.11-0.13$ & 0.01 & 0.09 & $0.09-0.10$ & 0.01 & ns \\
\hline Palmitic & C16:0 & 10.71 & $10.24-11.75$ & 0.47 & 10.65 & $10.15-11.77$ & 0.52 & ns \\
\hline Stearic & C18:0 & 2.72 & $2.52-2.99$ & 0.16 & 2.67 & $2.56-3.10$ & 0.18 & ns \\
\hline Arachidic & C20:0 & 0.93 & $0.86-1.06$ & 0.06 & 0.96 & $0.93-0.99$ & 0.02 & ns \\
\hline Behenic & $\mathrm{C} 22: 0$ & 2.06 & $1.90-2.26$ & 0.10 & 2.15 & $2.01-2.27$ & 0.09 & ns \\
\hline \multicolumn{9}{|c|}{ Monounsaturated fatty acids } \\
\hline Palmitoleic & C16:1 & 0.78 & $0.61-1.08$ & 0.15 & 0.71 & $0.64-1.06$ & 0.14 & ns \\
\hline Oleic & C18:1cis-9 & 50.66 & $50.13-50.82$ & 0.23 & 51.06 & $50.83-51.23$ & 0.15 & ns \\
\hline Eicosenoic & C20:1 n-9 & 3.00 & $2.84-3.15$ & 0.09 & 3.31 & $3.11-3.69$ & 0.21 & ns \\
\hline Erucic & C22:1 n-9 & 0.72 & $0.69-0.77$ & 0.03 & 0.64 & $0.47-0.78$ & 0.09 & ns \\
\hline \multicolumn{9}{|c|}{ Polyunsaturated fatty acids } \\
\hline Linoleic & C18:2 n-6 & 14.58 & $14.37-14.79$ & 0.13 & 13.83 & $13.58-14.16$ & 0.21 & ns \\
\hline$\alpha$-Linolenic & C18:3 n-3 & 12.75 & $11.95-13.25$ & 0.45 & 12.96 & $11.78-13.52$ & 0.52 & ns \\
\hline$\gamma$-Linolenic & C18:3 n-6 & 0.06 & $0.00-0.23$ & 0.09 & 0.04 & $0.00-0.16$ & 0.05 & ns \\
\hline Eicosadienoic & $C 20: 2 n-6$ & 0.18 & $0.15-0.20$ & 0.01 & 0.18 & $0.16-0.19$ & 0.01 & ns \\
\hline Eicosatrienoic & $\mathrm{C} 20: 3 \mathrm{n}-3$ & 0.09 & $0.01-0.14$ & 0.04 & 0.06 & $0.01-0.08$ & 0.02 & ns \\
\hline
\end{tabular}




\begin{tabular}{ccccccccc}
\hline Eicosapentaenoic C20:5 n-3 & 0.20 & $0.00-0.29$ & 0.13 & 0.16 & $0.12-0.30$ & 0.06 & $\mathrm{~ns}$ \\
\hline Other fatty acids & 0.05 & $0.00-0.25$ & 0.09 & 0.22 & $0.07-0.34$ & 0.08 & $\mathrm{~ns}$ \\
\hline$\Sigma$ SFA & 16.95 & $16.18-18.06$ & 0.55 & 16.83 & $16.35-18.30$ & 0.63 & $\mathrm{~ns}$ \\
\hline$\Sigma$ MUFA & 55.16 & $54.74-55.56$ & 0.24 & 55.72 & $55.59-55.98$ & 0.13 & $\mathrm{~ns}$ \\
\hline$\Sigma$ PUFA & 27.86 & $27.20-28.35$ & 0.42 & 27.23 & $25.87-27.78$ & 0.58 & $\mathrm{~ns}$ \\
\hline$\Sigma$ UFA & 83.02 & $81.94-83.57$ & 0.50 & 82.95 & $81.46-83.41$ & 0.62 & $\mathrm{~ns}$ \\
\hline
\end{tabular}

${ }^{I} S D-$ standard deviation; ${ }^{2} p: n s-p>0.05$;

SFA: saturated fatty acids, MUFA - monounsaturated fatty acids, PUFA - polyunsaturated fatty acids;

UFA: unsaturated fatty acids.

Musco et al. [21] reports for whole seeds of some L. albus cultivars a lower levels of unsaturated fatty acids, like palmitoleic ( $0.42 \%$ of FAME), oleic ( $46.50 \%$ of FAME) and $\alpha$-linoleic $(9.27 \%$ of FAME), but a higher content in linoleic (19.2\% of FAME) and erucic acids (1.57\% of FAME). The results of authors for other species show that the whole seeds of L. luteus present a content in total SFA (16.0\% of FAME) close to our results, and much lower in total MUFA (26.9\% of FAME), but twice higher for total PUFA (56.9\% of FAME).

The dehulling process does not influence $(p>0.05)$ the proportion of fatty acids in white lupine seeds. However, in absolute values there is both a slight increase of MUFA (especially C18:1 cis-9) and a decrease of PUFA (especially C18:2 n-6) and SFA.

In dehulled seeds, the fatty acids from the Omega 9 series, namely C18:1 cis-9 (oleic) and C20:1 n9 (eicosenoic), as well as the C18:3 n-3 ( $\alpha$-Linolenic) from the Omega 3 series, are found in a larger proportion than in LWS, with an average of $0.20-0.40$ percentage points.

To our knowledge, the literature presents only a few reports concerning the effect of dehulling lupine seeds on the fatty acids profile and nutritional quality of fats. Thus, Suchý et al. [47] support that the level of polyunsaturated fatty acids increases after dehulling the seeds (belonging to L. albus, L. angustifolius, L. luteus species) and the individual groups of fatty acids increase on average with $20.04-25.18 \%$, aspects not found in the present research. More recently, Volek et al. [20] report a total content in SFA by $9.96 \%$ of FAME and in PUFA by $24.50 \%$ of FAME only for dehulled lupine seeds (L. albus cv. Zulika), values that are considerably lower than our results. However, the 65.54\% of FAME level reported for MUFA is obviously higher. This is due to the higher concentration in oleic (57.72\% of FAME) and eicosenoic (5.21\% of FAME) fatty acids, compared to our results. Regarding some of the polyunsaturated fatty acids, the level reported by the authors for linoleic acid is comparable $(12.52 \%$ vs. $13.83 \%$ of FAME), but the level of $\alpha$-linolenic acid is considerably lower ( $7.89 \%$ vs $12.96 \%$ of FAME). The utilization of certain vegetal sources rich in essential fatty acids in farm animal feeds has been shown to significantly improve the nutritional value of animal origin products intended for human consumption [48, 49].

The effect of dehulling lupine seeds on the ratio of FA groups and several health lipid quality indices is presented in Table 3 . The results show that the dehulling process does not influence $(\mathrm{p}$ $>0.05$ ) the ratio of FA groups.

The UFA/SFA report highlights the degree of lipids unsaturation, and our results reveal favorable values for lupine seeds (LWS and LDS). The UFA/SFA ratio (of 4.91) that we obtained in the case of LWS is comparable to the values reported by Calabrò et al. [46] for several cultivars of white lupine (4.86 - 5.78). In the case of the PUFA/SFA report, the value obtained (1.65) is within the limits reported by the authors (1.53 - 1.97). Comparing these ratios of FA groups obtained in this research for L. albus, with the results of some other studies for other lupine species, it can be noted that L. luteus possess considerably higher values, but $L$. angustifolius has much lower ones [22].

From a nutritional point of view, an important aspect is the adequate ratio of $n-3 / n-6$ acids. It is high in both LWS (0.88) and LDS (0.94), being not different $(p>0.05)$. According to Simopoulos et al. 
[50], a n-3/n-6 ratio close to $1: 1$ is considered optimal for adult human health. Boschin et al. [23] report values comparable to ours (0.74). However, other values of $n-3 / n-6$ ratio presented in the literature are obviously lower with regard to whole seeds of L. albus: 0.55 [51]; 0.43 - 0.73 [46]; $L$. luteus: 0.19 [22] and L. angustifolius: 0.21 [21], 0.27 [22].

High values of the polyunsaturation index (PI) of white lupine seeds indicate the high level of PUFAs, an aspect considered important for human health due to implications in regulating blood cholesterol levels $[52,53]$. The PI obtained for whole seeds is comparable to the one reported by Mierlita et al. [24] for the L. albus cv. Amiga (41.83) and cv. Energy (36.57).

From the perspective of human health, the thromobogenic (TI) and atherogenic index (AI) highlight the predisposition for the incidence of cardiovascular diseases and express the relation between saturated (pro-thrombo/atherogenic) and unsaturated (anti-thromobo/atherogenic) lipids [54]. These indexes show similar low values and do not change $(\mathrm{p}>0.05)$ after dehulling. Lower TI and AI values are reported by Calabro et al. [46], highlighting the variability according to the year of seed cultivation, TI being $0.13-0.14$ and AI being $0.08-0.09$. Musco et al. [21] obtain a value similar to ours for TI (0.18) for L. albus cv. Lutteur, but for the other analyzed cultivars the values are lower and variable, ranging from 0.143 to 0.156 . For yellow lupine cultivars, the values are between 0.092 0.106. Regarding AI, the authors report lower values than ours, respectively $0.092-0.105$ for L. albus and $0.058-0.061$ for L. luteus. However, whole seeds of L. angustifolius have thrombogenic and atherogenic indices higher than those obtained in the present research; the TI values are between 0.297 - 0.390 and AI between $0.152-0.179$ [21].

Table 3. The effect of dehulling on the ratios and health lipid quality indices of L. albus cv. Amiga seeds

\begin{tabular}{|c|c|c|c|c|c|c|c|}
\hline \multirow{2}{*}{ Health lipid indices } & \multicolumn{3}{|c|}{ Whole seeds } & \multicolumn{3}{|c|}{ Dehulled seeds } & \multirow{2}{*}{$\mathrm{p}^{2}$} \\
\hline & $\begin{array}{l}\text { Mean } \\
(n=8)\end{array}$ & Min.-Max. & $\mathrm{SD}^{1}$ & $\begin{array}{l}\text { Mean } \\
(\mathrm{n}=8)\end{array}$ & Min. - Max. & $\mathrm{SD}^{1}$ & \\
\hline PUFA / SFA & 1.65 & $1.51-1.75$ & 0.07 & 1.62 & $1.41-1.70$ & 0.09 & ns \\
\hline MUFA / SFA & 3.26 & $3.03-3.41$ & 0.11 & 3.31 & $3.04-3.41$ & 0.12 & $\mathrm{~ns}$ \\
\hline UFA / SFA & 4.91 & $4.54-5.17$ & 0.18 & 4.93 & $4.45-5.10$ & 0.21 & ns \\
\hline$n-3$ FA & 13.04 & $12.08-13.61$ & 0.51 & 13.17 & $12.01-13.65$ & 0.51 & ns \\
\hline n-6 FA & 14.82 & $14.70-15.12$ & 0.13 & 14.05 & $13.82-14.33$ & 0.18 & $*$ \\
\hline$n-3 / n-6$ FA & 0.88 & $0.80-0.92$ & 0.04 & 0.94 & $0.87-0.98$ & 0.04 & ns \\
\hline PI & 40.07 & $38.69-41.00$ & 0.80 & 39.74 & $37.16-40.62$ & 1,09 & ns \\
\hline $\mathrm{TI}$ & 0.18 & $0.17-0.21$ & 0.01 & 0.18 & $0.17-0.21$ & 0.01 & ns \\
\hline $\mathrm{AI}$ & 0.14 & $0.13-0.16$ & 0.01 & 0.14 & $0.13-0.16$ & 0.01 & ns \\
\hline HFA & 11.06 & $10.53-12.14$ & 0.50 & 10.92 & $10.43-12.04$ & 0.52 & ns \\
\hline hFA & 78.52 & $77.33-79.17$ & 0.58 & 78.29 & $76.70-78.88$ & 0.68 & ns \\
\hline $\mathrm{h} / \mathrm{H}$ & 7.12 & $6.37-7.52$ & 0.35 & 7.18 & $6.37-7.56$ & 0.38 & ns \\
\hline
\end{tabular}

${ }^{1} S D-$ standard deviation; ${ }^{2} p: n s-p>0.05 ; *-p<0.05$;

SFA: saturated fatty acids, MUFA: monounsaturated fatty acids, PUFA: polyunsaturated fatty acids;

UFA: unsaturated fatty acids; FA: fatty acid;

PI: polyunsaturated index; TI: thrombogenic index; AI: Atherogenic Index;

HFA: Hypercholesterolemic Fatty Acids (C12:0 + C14:0 + C16:0); hFA: hypocholesterolemic Fatty

Acids (C18:1 + polyunsaturated FA); h/H: hypocholesterolemic/Hypercholesterolemic FA.

White lupine seeds are characterized by the high presence of fatty acids with hypocholesterolemic effects (hFA), aspect that also results from the high ratio of $\mathrm{h} / \mathrm{H}$ (hypocholesterolemic/ hypercholesterolemic FA). This level is relatively similar $(\mathrm{p}>0.05)$ for LWS and LDS. The high value of the $\mathrm{h} / \mathrm{H}$ index indicates the presence of valuable lipids, with a real potential to reduce the plasma cholesterol $[36,55]$. These hypocholesterolemic properties of lupine seeds have been demonstrated for rats [56]. 


\section{Conclusions}

According to the results obtained in this study, dehulling lupine seeds influences $(p<0.05)$ the level of crude protein and crude fibre, but does not affect $(p>0.05)$ the content of ether extract, crude ash and nitrogen-free extract. Through dehulling white lupine seeds, the crude protein content increased from $43.16 \%$ to $51.69 \%$ of DM and the one of crude fibre decreased from $14.15 \%$ to $4.35 \%$ of DM, which suggests an increase in the content of nutrients, but also an improvement of their digestibility and absorption, as well as the degree of valorification. The fatty acid profile of lupine seeds is not influenced $(\mathrm{p}>0.05)$ by the dehulling process. The major fatty acid in the whole and dehulled seeds is oleic acid (50.66 - 51.06\% of FAME), followed by linoleic acid (14.58 - 13.83) and $\alpha$-Linolenic (12.75 - 12.96). The appropriate $n-3 / n-6$ FA ratio $(0.88$ - 0.94) and the favorable polyunsaturated index (40.07 - 39.74) highlight the high content in polyunsaturated fatty acids (especially from the n-3 series), which attribute the quality of valuable source of essential fatty acids. The low values of thrombogenic (0.18) and atherogenic (0.14) indexes indicate that lupine seeds are suitable for human nutrition. In addition, the high ratio values of UFA/SFA, PUFA/SFA and h/H, as well as the low values of SFA, AI and TI confirm the valuable nutritional value of the lipid fraction in white lupine seeds.

\section{References}

1.LUCAS, M.M., STODDARD, F.L., ANNICCHIARICO, P., FRÍAS, J., MARTÍNEZVILlALUENGA, C., SUSSMANN, D., DURANTI, M., SEGER, A., PETER, M.Z., PUEYO, J.J., The future of lupin as a protein crop in Europe, Front. Plant Sci., 6, 2015, 1-6.

2. ANNICCHIARICO, P., HARZIC, N., CARRONI, A.M., Adaptation, diversity, and exploitation of global white lupin (Lupinus albus L.) landrace genetic resources, Field Crop Res., 119(1), 2010, 114124.

3.MCNEILL, A.M., FILLERY, I.R.P., Field measurement of lupin belowground nitrogen accumulation and recovery in the subsequent cereal-soil system in a semi-arid Mediterranean-type climate, Plant Soil, 302, 2008, 297-316.

4. WEISSKOPF, L., AKELLO, P., MILLERET, R., KHAN, Z.R., SCHULTHESS, F., GOBAT J.M., LE BAYON, R.C., White lupin leads to increased maize yield through a soil fertility-independent mechanism: a new candidate for fighting Striga hermonthica infestation?, Plant and Soil, 319(1-2), 2008, 101-114.

5.KSIĘŻAK, J., STANIAK, M., BOJARSZCZUK J., Nutrient contents in yellow lupine (Lupinus luteus L.) and blue lupine (Lupinus angustifolius L.) cultivars depending on habitat conditions, Pol. $J$. Environ. Stud., 27(3), 2018, 1145-1153.

6. PÍSA RÍKOVÁ, B., ZRALÝ, Z., Nutritional value of lupine in the diets for pigs (a review), Acta Vet. Brno, 78(3), 2009, 399-409.

7. ROMEO, F., FABRONI, S., BALliSTRERI, G., MUCCILli, S., SPINA, A., RAPISARDA, P., Characterization and antimicrobial activity of alkaloid extracts from seeds of different genotypes of Lupinus spp., Sustainability, 10(3), 2018, 1-12.

8.SMULIKOWSKA, S., KONIECZKA, P., CZERWINSKI, J., MIECZKOWSKA, A., JANKOWIAK, J., Feeding broiler chickens with practical diets containing lupin seeds (L. angustifolius or L. luteus): effects of incorporation level and mannanase supplementation on growth performance, digesta viscosity, microbialfermentation and gut morphology, J. Anim. Feed Sci., 23, 2014, 64-72.

9. CAPRARO, J., MAGNI, C., FONTANESI, M., BUDELli, A., DURANTI, M., Application of twodimensional electrophoresis to industrial process analysis of proteins in lupin-based pasta, Food Sci. Technol., 41(6), 2008, 1011-1017.

10. MAGHAYDAH, S., ABDUL-HUSSAIN, S., AJO, R., TAWALBEH, Y., ELSAHORYI, N., Effect ofl lupine flour on baking characteristics of gluten free cookies, Adv. J. Food Sci. Technol., 5(5), 2013, 600-605.

11. ERBERSDOBLER, H.F., BARTH, C.A., JAHREIS, G., Legumes in human nutrition Nutrient 
content and protein qualityof pulses, Ernaehr. Umsch. Int., 64, 2017, 134-139.

12. KALOGEROPOULOS, N., CHIOU, A., IOANNOU, M., KARATHANOS, V.T., HASSAPIDOU, M., ANDRIKOPOULOS, N.K., Nutritional evaluation and bioactive microconstituents (phytosterols, tocopherols, polyphenols, triterpenic acids) in cooked dry legumes usually consumed in the Mediterranean countries, Food. Chem., 121(3), 2010, 682-690.

13. KHAN, M.K., KARNPANIT, W., NASAR-ABBAS, S.M., HUMA, Z., JAYASENA, V., Phytochemical composition and bioactivities of lupin: a review, Food Sci. Technol., 50(9), 2015, 2004-2012.

14. DELEANU, M., SANDA, G., STANCU, C., POPA, M., SIMA, A., Profiles of fatty acids and the main lipid peroxidation products of human atherogenic low density lipoproteins, Rev. Chim., 67(1), 2016, 8-12.

15. COPOlOVICI, D., BUNGAU, S., BOSCENCU, R., TIT, D.M., COPOLOVICI, L., The fatty acids composition and antioxidant activity of walnut cold press oil, Rev. Chim., 68(3), 2017, 507-509.

16. SIMEANU, D., NISTOR, A., AVARVAREI, B.V., BOISTEANU, P.C., Chemical composition and nutritional evaluation of pasteurized egg melange. Rev. Chim., 70(4), 2019, 1390-1395.

17. CIOBANU, M., BOISTEANU, P.C., SIMEANU, D., POSTOLACHE, A., LAZAR, R., VINTU, C., Study on the profile of fatty acids of broiler chicken raised and slaughtered in industrial system, Rev. Chim., 70(11), 2019, 4089-4094.

18. CHILOMER, K., KASPROWICZ-POTOCKA, M., GULEWICZ, P., FRANKIEWICZ, A., The influence of lupin seed germination on the chemical composition and standardized ileal digestibility of protein and amino acids in pigs, J. Anim. Physiol. Anim. Nutr., 97(4), 2012, 639-646.

19. YILMAZ, S., ATAK, M., ERAYMAN, M., Comparison of chemical composition in lupine (Lupinus spp.) species, Rev. Chim., 66(3), 2015, 324-327.

20. VOLEK, Z., BURES̆, D., UHLÍŔRVÁ, L., Effect of dietary dehulled white lupine seed supplementation on the growth, carcass traits and chemical, physical and sensory meat quality parameters of growing-fattening rabbits, Meat Science, 141, 2018, 50-56.

21. MUSCO, N., CUTRIGNELli, M.I., CALABRÒ, S., TUDISCO, R., INFASCELlI, F., GRAZIOLI, R., LO PRESTI, V., GRESTA, F., CHIOFALO, B., Comparison of nutritional and antinutritional traits among different species (Lupinus albus L., Lupinus luteus L., Lupinus angustifolius L.) and varieties of lupin seeds, J. Anim. Physiol. Anim. Nutr., 101(6), 2017, 1227-1241.

22. CHIOFALO, B., PRESTI, V.L., CHIOFALO, V., GRESTA, F., The productive traits, fatty acid profile and nutritional indices of three lupin (Lupinus spp.) species cultivated in a Mediterranean environment for the livestock, Anim. Feed Sci. Tech., 171(2-4), 2012, 230-239.

23. BOSCHIN, G., D'AGOSTINA, A., ANNICCHIARICO, P., ARNOLDI, A., Effect of genotype and environment on fatty acid composition of Lupinus albus L. seed, Food Chem., 108(2), 2008, 600606.

24. MIERlitA, D., SIMEANU, D., POP, I.M., CRISTE, F., POP, C., SIMEANU, C., LUP, F., Chemical composition and nutritional evaluation of the lupine seeds (Lupinus albus L.) from lowalkaloid varieties, Rev. Chim., 69(2), 2018, 453-458.

25. EMBABY H.E.S., Effect of soaking, dehulling, and cooking methods on certain antinutrients and in vitro protein digestibility of bitter and sweet lupin seeds, J. Food Sci. Biotechnol., 19(4), 2010, 1055-1062.

26. OMER, M.A.M., MOHAMED, E.A., AHMED, I.A.M., YAGOUB, A.A., BABIKER, E.E., Effect of different processing methods on anti-nutrients content and protein quality of improved lupin (Lupinus albus L.) cultivar seeds, Turk. J. of Agriculture - Food Science and Technology., 4(1), 2016, 9-16.

27. MASOERO, F., PULIMENO, A.M., ROSSI, F., Effect of extrusion, espansion and toasting on the nutritional value of peas, faba beans and lupins, Ital. J. Anim. Sci., 4(2), 2005, 177-189.

28. PÍSAŘÍKOVÁ, B., ZRALY, Z., BUNKA, F., TRCKOVA, M., Nutritional value of white lupine cultivar Butan in diets for fattening pigs, Vet. Med-Czech, 53(3), 2008, 124-134. 
29. SAEZ, P., BORQUEZ, A., DANTAGNAN, P., HERNANDEZ, A., Effects of dehulling, steamcooking and microwave-irradiation on digestive value of white lupin (Lupinus albus) seed meal for rainbow trout (Oncorhynchus mykiss) and Atlantic salmon (Salmo salar), Arch. Anim. Nutr., 69(2), 2015, 143-157.

30. BARNEVELD VAN, R.J., Understanding the nutritional chemistry of lupin (Lupinus spp.) seed to improve livestock production efficiency, Nutr. Res. Rev., 12(2), 1999, 203-230.

31. BÄHR, M., FECHNER, A., HASENKOPF, K., MITTERMAIER, S., JAHREIS, G., Chemical composition of dehulled seeds of selected lupin cultivars in comparison to pea and soya bean, Food Sci. and Tech., 59, 2014, 587-590.

32. ***AOAC International, Official Methods of Analyses. 18th ed., Association of Official Analytical Chemists, Gaithersburg MD, 2005, USA.

33. SIBBALD, I.R., Metabolizable energy in poultry nutrition, BioScience, 30(11), 1980, 736-741.

34. TIMMONS, J.S., WEISS, W.P., PALMQUIST, D.L., HARPER, W.J., Relationships among dietary roasted soybeans, milk components, and spontaneous oxidized flavor of milk, J. Dairy Sci., 84, 2001, 2440-2449.

35. ULBRICHT, T.L.V., SOUTHGATE, D.A.T., Coronary heart disease: seven dietary factors, The Lancet, 338(8773), 1991, 985-992.

36. FERNANDEZ, M., ORDÓÑEZ, J.A., CAMBERO, I., SANTOS, C., PIN, C., DE LA HOZ, L., Fatty acid compositions of selected varieties of Spanish dry ham related to their nutritional implications, Food. Chem., 9, 2007, 107-112.

37. VEČEREK, V., SUCHÝ, P., STRAKOVÁ, E., MACHÁCEK, M., In: PALTA, J.A., BERGER, J.B, Lupins for health and wealth, Canterbury, 2008, 123-126.

38. LAUDADIO, V., TUFARELLI, V., Dehulled-micronised lupin (Lupinus albus L. cv. Multitalia) as the main protein source for broilers: influence on growth performance, carcass traits and meat fatty acid composition, J. Sci. Food Agr., 91(11), 2011, 2081-2087.

39. MERA-ZÚÑIGA, F., PRO-MARTÍNEZ, A., ZAMORA-NATERA, J.F., SOSA-MONTES, E., GUERRERO-RODRÍGUEZ, J.D., MENDOZA-PEDROZA, S.I., CUCA-GARCÍA, J.M., LÓPEZROMERO, R.M., CHAN-DÍAZ, D., BECERRIL-PÉREZ, C.M., VARGAS-GALICIA, A.J., BAUTISTA-ORTEGA, J., Soybean meal substitution by dehulled lupine (Lupinus angustifolius) with enzymes in broiler diets, Asian-Australas J. Anim. Sci., 32, 2018, 564-573.

40. MIECZKOWSKA, A., JANSMAN, A.J.M., KWAKKEL, R.P., SMULIKOWSKA, S., Effect of dehulling and $\alpha$-galactosidase supplement on the ileal digestibility of yellow lupin based diets in broiler chickens and adult roosters, J. Anim. Feed Sci., 14(2), 2005, 297-304.

41. GRELA, E.R., SAMOLIŃSKA, W., KICZOROWSKA, B., KLEBANIUK, R., KICZOROWSKI P., Content of minerals and fatty acids and their correlation with phytochemical compounds and antioxidant activity of leguminous seeds, Biol. Trace. Elem. Res., 180(2), 2017, 338-348.

42. VOLEK, Z., VOLKOVÁ, L., MAROUNEK, M., Effect of a diet containing white lupin hulls (Lupinus albus cv. Amiga) on total tract apparent digestibility of nutrients and growth performance of rabbits, World Rabbit Sci., 21(1), 2013, 17-21.

43. MIERLITA, D., Studies on cultivation suitability and nutritional characterization of lupine alkaloid-free varieties, Annals Univ. of Oradea: Ecotoxicology, Animal Husbandry and Food Industry Technologies, 11, 2012, 501-508.

44. RYBIŃSKI, W., ŚWIĘCICKI, W., BOCIANOWSKI, J., BORNER, A., STARZYCKA-KORBAS, E., STARZYCKI, M., Variability of fat content and fatty acids profiles in seeds of a Polish white lupin (Lupinus albus L.) collection., Genet. Resour. Crop Ev., 65(2), 2018, 417-431.

45. VOLEK, Z., MAROUNEK, M., Effect of feeding growing-fattening rabbits a diet supplemented with whole white lupin (Lupinus albus cv. Amiga) seeds on fatty acid composition and indexes related to human health in hind leg meat and perirenal fat, Meat Sci., 87(1), 2011, 40-45.

46. CALABRÒ, S., CUTRIGNELli, M.I., LO PRESTI, V., TUDiSCO, R., CHIOFALO, V., GROSSI, M., INFASCELLI, F., CHIOFALO, B., Characterization and effect of year of harvest on the 
nutritional properties of three varieties of white lupine (Lupinus albus L.), J. Sci. Food Agr., 95(15), 2015, 3127-3136.

47. SUCHÝ, P., STRAKOVÁ, E., KROUPA, L., VECEREK, V., In: PALTA, J.A., BERGER, J.B. (Eds.), The fatty acid content of oil from seeds of some lupin varieties, Proceedings of the 12th International Lupin Conference, Canterbury, New Zeeland, 2008, 188-191.

48. LUP, F., POP, I.M., SIMEANU, D., VICAS, S., SIMEANU, C., MIERLITA, D., Research regarding fatty acid profile and health lipid indices in the lambs meat of employing feed supplemented with different vegetable oils, Rev. Chim., 69(1), 2018, 222-227.

49. CRISTE, F.L., MIERLITA, D., SIMEANU, D., BOISTEANU, P.C., POP, I.M., GEORGESCU, B., NACU, G., Study of fatty acids profile and oxidative stability of egg yolk from hens fed a diet containing white lupine seeds meal, Rev. Chim., 69(9), 2018, 2454-2460.

50. SIMOPOULOS, A., The importance of the ratio of omega-6/omega-3 essential fatty acids, Biomed. Pharmacother., 56(8), 2002, 365-379.

51. ARNOLDI, A., GRECO, S., Nutritional and nutraceutical characteristics of lupin protein, Nutrafoods, 10, 2011, 23-29.

52. JENKINSON, A., FRANKLIN, M., WAHLE, K., DUTHIE, G., Dietary intakes of polyunsaturated fatty acids and indices of oxidative stress in human volunteers, Eur. J. Clin. Nutr., 53(7), 1999, 523528.

53. WANG, S.P., CHEN, Y.H., LI, H., Association between the levels of polyunsaturated fatty acids and blood lipids in healthy individuals, Exp. Ther. Med., 4(6), 2012, 1107-1111.

54. GHAENI, M., GHAHFAROKHI, K.N., Fatty acids profile, atherogenic (IA) and thrombogenic (IT) health lipid indices in Leiognathusbindus and Upeneussulphureus, J. Marine Sci. Res. Dev., 3(4), 2013, 1-3.

55. MIERLITA, D., POP, I., LUP, F., SIMEANU, D., VICAS, S., SIMEANU, C., The fatty acids composition and health lipid indices in the sheep raw milk under a pasture-based dairy system, Rev. Chim., 69(1), 2018, p. 160-165.

56. FAYED, S.A., OSMAN, M., MAHMOUD, G.I., ROMEILAH, R.M., Lupin seeds lower plasma lipid concentrations and normalize antioxidant parameters in rats, Grasas Aceites, 62(2), 2011, 162170.

$\overline{\text { Manuscript received: } 11.10 .2019}$ 